\title{
Don Lindberg's Wisdom and Influence: A Personal Perspective
}

\author{
Rashid L. BASHSHUR Ph.D. ${ }^{1}$ \\ Professor Emeritus, University of Michigan, U.S.A.
}

\begin{abstract}
Keywords: Donald A.B. Lindberg M.D., U.S. National Library of Medicine,
\end{abstract} telemedicine, mentorship

I had the good fortune to meet Donald and Mary Lindberg during the first national conference of the American Telemedicine Association in Atlanta in 1994. I remember the encounter vividly because it was a special event to commemorate and honor the tragic passing of their son Chris, an early advocate of telemedicine in that era I had met the year before. That encounter was brief, and little did I realize or think that it would be followed several years later by an eventful, rich, and rewarding experience that had a profound impact on my professional life.

In 2001, Don Lindberg invited me to attend a special telemedicine symposium in Bethesda, organized by the National Library of Medicine (NLM) to highlight the research findings on telemedicine funded by the NLM from 1994 to 2000. At lunch in NLM's cafeteria, Don asked about my impressions of the symposium and what issues remain to be addressed through further research. Toward the end of our discussion, he asked if I would consider spending a year or more at NLM as a resident scholar to pursue my research interests unencumbered by other work demands. Don said the Library would expect me to acknowledge NLM in anything I wrote while in residence. However, NLM would not restrict editorial initiatives or make other stipulations or requirements. Don added he might ask my views about important topics about telemedicine.

I thought the overture was unusually generous. It was an academician's dream and the best offer I have ever received. Candidly, my inner-most thoughts at the time were: 'this great man sees something in me that I am not sure I possess.'

Nonetheless, it was difficult for me to move my family to D.C. and, we did not act on the generous proposal at that time. Some five years later, I wrote to inquire whether the offer was viable and if I could work from Ann Arbor, Michigan. Don agreed and said I should work with Mike Ackerman on the arrangements. Mike turned out to be a walking encyclopedia on NLM's bureaucracy. With his guidance, efficiency, and kindness, we became life-long friends.

During that year, I wrote a few policy pieces that Don was interested in pursuing, particularly the use of telemedicine in disaster preparedness/response, and in facilitating large-scale clinical trials. I also started to collect materials for a History of Telemedicine book, which was later sponsored by the NLM and published in 2009 [1]. I returned to the fountainhead several times. Don consistently rewarded me with support for several national symposia and the publication of a series of journal articles on the empirical evidence that undergirds telemedicine research.

${ }^{1}$ Corresponding author: bashshur@med.umich.edu 
Although we met during the latter part of my career, Don had a profound effect on helping me achieve my ultimate dreams without asking for much in return other than to deliver on my promise. Indeed he was a giant of our time, a scholar of the highest order, a critical thinker, and a true pioneer in the development of telemedicine. Don was unique in many ways, perfectionist yet unpretentious, with varied interests but none superficially, and a precious dry sense of humor. Don also possessed the rare trait of seeing both the forest and the trees, each in proper perspective.

Looking back at the years gone by and the many people I met during my professional career, I can appreciate Don's unique qualities and his extraordinary influence in helping me achieve my potential. He was a steady and reliable source of support, guidance, and wisdom. He was never hesitant to express his point of view or point out how best to frame issues and text, yet he was disarming in his genuine courtesy and kindness. At times, he helped re-orient my thinking in a few words or hints. He was direct, thoughtful, and to the point, qualities that I always admired. Don could almost complete some of my sentences before I uttered them, almost as if he knew what I was would say.

He was honest and proper to a fault. I learned that if Don liked any of my ideas, they probably were reasonable. To my relief and sense of pride and humility, his comments were constructive and perceptive. He was a professor's professor. I truly appreciated his pedagogic shorthand in explaining complex things.

Returning to our interactions, Don provided advice on some health issues; he was genuinely interested in my health and wellbeing. In addition, it intrigued Don that I was educated at the American University of Beirut (AUB). Calvin Plimpton, AUB's President (1984-1987) and a friend of Don's, invited him to join the AUB faculty. From time to time, Don would test me on an esoteric topic. He asked me once where Argentina geographically was located in relation to the U.S. I missed that Argentina was located East - not just South - of the U.S. Although I flunked the quiz, Don smiled and said: 'you are alright.'

I will always miss Don's dry smile, his sense of purpose and destiny, and his ability to cut through clouds of uncertainties to arrive at the truth. I feel blessed for his presence in part of my life. Overall, Don was one of the most admirable people I have ever known or met. His loss leaves a deep void in my life.

\section{Reference}

[1] Bashshur RL, Shannon GW. History of telemedicine: evolution, context, and transformation. New York: Mary Ann Liebert Inc.; 2009. 